\title{
胸脇苦満の発現機序に関する病態生理学的考察
}

\author{
一胸脇苦満と横隔膜異常緊張との関連—
}

\author{
寺澤 捷年 \\ 千葉中央メディカルセンター和漢診療科，千葉，

\section{The Pathophysiological Mechanism of the Kyokyokuman : On the Relationship between Kyokyokuman and Tense Condition of Diaphragm}

\begin{abstract}
Katsutoshi TERASAWA
Department of Japanese-Oriental (Kampo) Medicine, Chiba Central Medical Center, 1835-1 Kasoricho, Wakaba-ku, Chiba 264-
\end{abstract} 0017, Japan

\begin{abstract}
In the previous article, the author reported on the relationship between shinkahiko and transport points. However, acupuncture manipulation to these points never diminished fullness in the chest and hypochondrium (kyokyokuman). Thus the author searched a new lump of back muscles and finally discovered that the infraspinatus muscle is a critical point which is closely rerated with kyokyokuman. The author also discovered that this point improves hiccup. It is well known that this lump is present in patients with shoulder stiffness and so on. Some patients with kyokyokuman present this lump simultaneously. This report intends to clarify a kyokyokuman that appears related tense condition of diaphragm, by means of both two concrete clinical cases and fifteen cases discussing to the pathophysiological background of this phenomenon.

Key words : kyokyokuman, diaphragm, hiccup, infraspinatus muscle, pathophysiology

要旨

筆者は先に心下㿋鞕と背部俞穴の関連を報告したところである。この報告において旁脊柱筋の硬結への施術に よって心下㾂鞭は消失するが，胸脇苦満は消失しないことを記した。そこで筆者は，改めて胸脇苦満と関連する背 部諸筋の硬結を探索し, 棘下筋の硬結が胸脇苦満と密接に関連することを発見した。またこの棘下筋硬結への施術 が吃逆を改善することも見出した。棘下筋の硬結は肩こりなどでも現れるがその中に胸脇苦満と同時にあらわれる ものがあることを明らかにした。本論文は棘下筋の硬結を手がかりに胸脇苦満が横隔膜の異常緊張と関連したもの であることを具体的な 2 症例および15症例を基にその病態生理学的背景を明らかにしようと意図したものである。 キーワード：胸脇苦満, 横隔膜, 吃逆, 棘下筋, 病態生理学
\end{abstract}

\begin{abstract}
緒言
先の報告において筆者は心下㿋鞕と旁脊柱筋の 硬結が密接に関連することを明らかにした。この報 告の中には胸脇苦満が併存する 5 症例があったが, 旁脊柱筋への置針・加温という施術によって併存し た胸脇苦満は軽減しないことを記した。そこで新た に胸脇苦満と関連する背部諸筋の硬結を探索したと ころ, 肩胛骨・棘下筋の硬結が該当することを見出 した。細野史郎は胸脇苦満を横隔膜症候群とも呼ぶ べき病態であると記しているが2 , 横隔膜の運動と 知覚は頸髄 $3 \cdot 4 \cdot 5$ (以下 C $3 \cdot 4 \cdot 5$ と表記)
\end{abstract}

に起始する横隔神経であり, 他方, 棘下筋は C 5 ・ 6 に由来する上肩胛神経によって支配されている。 棘下筋の硬結を緩める施術が横隔膜の異常緊張を解 除すると仮定すると吃逆にも有効であると推測され たので，吃逆症例にも試みたところ明らかな改善を 得た。筆者は細野史郎の学説 ${ }^{2)}$ 強化する意図の下 に, 胸脇苦満という徵候が横隔膜の異常緊張に関連 したものであることを, 棘下筋硬結を手がかりに病 態生理学的に検討したので報告する。

\section{対象と方法}

症例呈示(1) 横隔膜の異常緊張が示唆された48歳, 


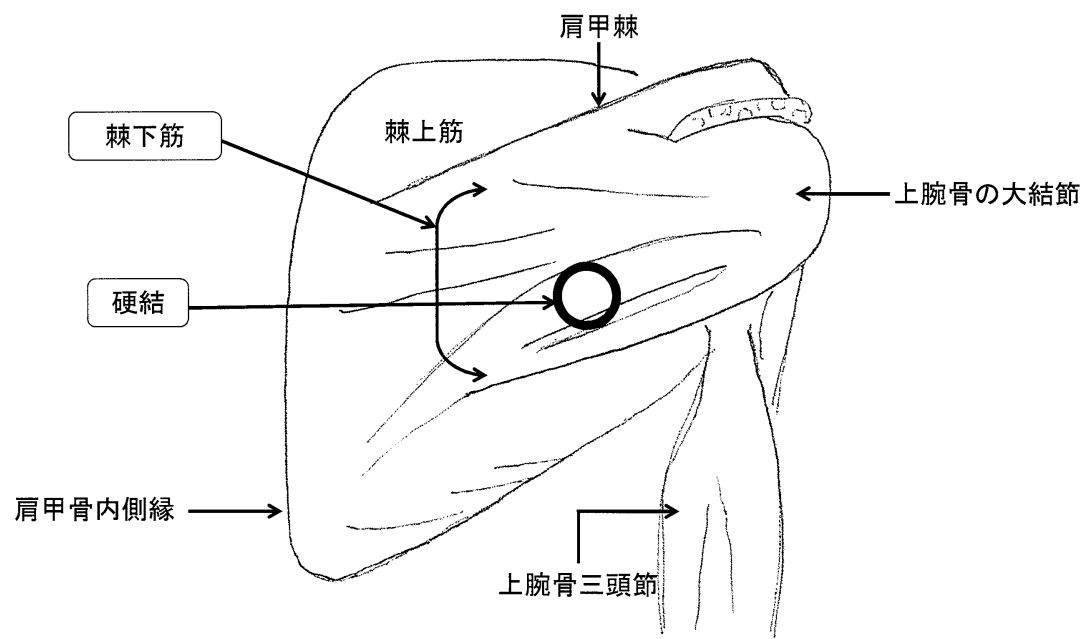

図 1 棘下筋硬結の発現部位

文献 3 ）を参考に描き，硬結の好発部位を示した。手之太陽小腸経の天 宗（SI11）に近い部位である。

表 1 施術前後の呼吸機能検査成績

\begin{tabular}{|c|c|c|c|c|c|c|}
\hline & \multirow{2}{*}{ 単位 } & \multirow{2}{*}{ 予測 } & \multicolumn{2}{|c|}{ 施術前 } & \multicolumn{2}{|c|}{ 施術後 } \\
\hline & & & 実測 & $\%$ & 実測 & $\%$ \\
\hline 肺活量 & L & 3.11 & 2.33 & 74.8 & 2.62 & 84.1 \\
\hline 一回換気量 & L & & 0.40 & & 0.45 & \\
\hline 予備呼気量 & L & & 0.60 & & 0.88 & \\
\hline 予備吸気量 & L & & 1.33 & & 1.29 & \\
\hline \%肺活量判定指数 & & & $\mathrm{F}-$ & & $\mathrm{F}-$ & \\
\hline 努力性肺活量 & L & 2.98 & 2.47 & 82.9 & 2.67 & 89.6 \\
\hline 1秒量 & L & 2.50 & 2.01 & 80.3 & 2.00 & 79.9 \\
\hline 1 秒率 & $\%$ & 85.2 & 81.4 & 95.5 & 71.9 & 87.9 \\
\hline 最大呼気流量 & $\mathrm{L} / \mathrm{s}$ & 6.84 & 4.23 & 61.8 & 5.26 & 76.9 \\
\hline MMF & $\mathrm{L} / \mathrm{s}$ & 3.25 & 1.85 & 56.9 & 1.50 & 46.0 \\
\hline V50 & $\mathrm{L} / \mathrm{s}$ & 3.64 & 2.03 & 55.7 & 1.72 & 47.1 \\
\hline V25 & $\mathrm{L} / \mathrm{s}$ & 1.49 & 0.90 & 60.3 & 0.62 & 41.7 \\
\hline $\mathrm{V} 25 / \mathrm{Ht}$ & $\mathrm{L} / \mathrm{s} / \mathrm{m}$ & 0.928 & 0.560 & 60.3 & 0.387 & 41.7 \\
\hline エアトラッピング & & & -6.05 & & -1.95 & \\
\hline (F)V25/Ht & & & $\mathrm{F}+$ & & $\mathrm{F++}$ & \\
\hline OI & & & 2.33 & & 2.87 & \\
\hline
\end{tabular}

女性の一症例

主 訴：左股関節周囲鈍痛と両下肢の冷え。胸膈 の圧迫感。

既往歴・家族歴：幼少時に気管支喘息。

現病歴 : X-4 年の冬から主訴が出現。職場での 仕事が立て込んでくると肩こりと易怒性を自覚。顔 は火照るが下肢の冷感があり，冬期に主訴は増悪し た。

現 症：身 長 $160 \mathrm{~cm}$, 体 重 $54 \mathrm{Kg}$, 血 圧 $120 / 72$ $\mathrm{mmHg}$ 。下肢の表在知覚, 深部腱反射, 筋力などに
は異常を認めなかった。左股関節の MRI 所見にも 異常は無かった。

漢方医学的所見：自覚的には右側優位の季肋部周 辺の膨満感があった。また，「胸全体が締め付けら れているようです」とのことであった。顔面の煩部 が紅潮し，口唇の乾燥を認めた。上熱下寒があり， 下肢末梢の冷えを認めた。脈候はやや浮，弱，細。 舌候は正常紅で湿潤した微白苔。腹力はやや軟弱で 右季肋下部の抵抗と圧痛があり，右胸髄 7 (Th 7 ) 領域の皮膚に痛覚過敏を認めた。そこで腹臥位とさ 
せ棘下筋3)の硬結の有無を触診したところ右側で劇 痛，左側では軽度の圧痛を伴う凝りを認めた（図 1 )。この硬結部位は手之太陽小腸経の天宗（SI11） 近傍である。

治療経過：本症例は X-2 年から柴胡桂枝乾姜湯 証と診断し，これを服用していたが，冬期の増悪が 改善し, 日常生活には支障のない状態で推移してい たものである。しかし, 柴胡桂枝乾姜湯の服用に よっても時に胸脇苦満が出現するという経過を辿っ ていた。背診によって両側の棘下筋の明らかな有痛 性の硬結を認めたが，この硬結への施術が横隔膜の 異常緊張を解除するとすれば，呼吸機能に影響を与 えると考えた。そこで, 施術前後の呼吸機能を検査 することとし，この検査の目的に同意を得て呼吸機 能検査を施術の前後で実施した。その検査結果を表 1 に掲げた。施術前は拘束性と判定される成績で あったが、これが施術により正常化していた。

施術はセイリン鍼 L type No. $3(0.20 \mathrm{~mm}) \times 40 \mathrm{~mm}$ を肩胛骨に達するまで皮膚面に対して垂直に約 1.5 $\mathrm{cm}$ 刺入置針し, 電気温針器（サンライズ工業，新 潟 $)^{4)}$ の第 2 段階で10分間加温した。この左右の棘下 筋への施術によって, 自覚的には胸の締め付けられ る感じと季肋下部周辺の膨満感が改善し, 皮膚の痛 覚過敏挹よび季肋下部の圧痛と抵抗は全く消失した。

4 週間後に再診。前回, 施術を行った夜は今まで に無く熟睡出来たと言う。呼吸も楽になった。主訴 の一つであった股関節周囲の違和感も半減し, この 4 週間, とても快適に過ごせたという。皮膚の痛覚 過敏は消失していた。以後も柴胡桂枝乾姜湯の服薬 を継続しているが, 棘下筋の硬結と皮虐の痛覚過敏 は再び現れることもなく，経過は順調である。

症例呈示(2) 吃逆が 3 日間持続した42歳，男性の 一症例。

主 訴：3 日前から睡眠中も持続する吃逆。

現病歴：X-3 日の夕刻, 忘年会がありビールを 飲み会食をした。その直後から吃逆が出現。息こら えなど様々に吃逆を止める事を行ったが全く無効で あった。吃逆は夜間の睡眠時にも継続し, 翌日も止 まらず当院内科を受診。メトクロピラミド（プリン ペラン $\left.{ }^{\circledR}\right)$ 注射液 $10 \mathrm{mg}$ の筋肉注射を受けたが無効 で，内科医からの紹介で和漢診療科を受診した。

現 症: 身 長 $170 \mathrm{~cm}$, 体 重 $65 \mathrm{Kg}$, 血 圧 $126 / 74$ $\mathrm{mmHg}$, 脈拍78回/分・整。顔貌は苦悶状であった

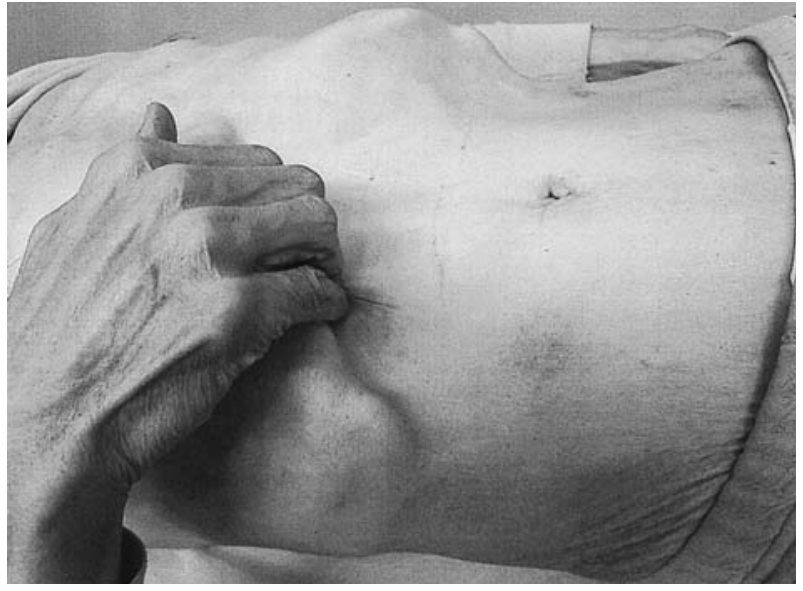

図 2 MRI 撮影に際しての胁骨弓下の手指による圧迫

が，吃逆が約15秒間隔で見られる他には悪心，嘔吐， 頭痛など随伴する症状は無かった。身体所見にも異 常は認められなかった。

漢方医学的所見：顔面はやや蒼白で苦悶状を呈し ていた。脈候は弱・弦。舌候は正常紅で微白苔。腹 候は腹力中等度で心窩部に明らかな皮膚温の低下を 認めたが，心下㾂鞕や胸脇苦満は無かった。

治療経過：漢方医学的には呉荣䓎湯証と診断した。 吃逆は横隔膜の間代性痤攣であることから，背診を 行い左右の棘下筋硬結の有無を触診したところ右側 優位で激しい痛みを訴えた。そこで，この硬結部 （両側）に置針し，電気温針器による加温を実施し た。施術開始後約 3 分間で吃逆は止まったが，型ど おり10分間の置針と加温を行った。正月を迎えるこ とから酒は憪酒やお湯割りを飲むように勧め, ビー ルは禁じた。呉茱莫湯エキス剤を 1 週間分処方。 1 週間後に再診の予約をしたが，施術後，吃逆は全く 起こらなかったということで，予約は感謝の言葉と ともに取り消された。呉荣朝湯エキス剤は全量服用 したとのことであった。な拝者はこの棘下筋硬結 への施術が吃逆を治すことを他の 4 症例で実施し,

有効性を確認している。

\section{15症例での検討}

対象は和漢診療科外来を受診中の患者で, 胸脇苦 満（季肋下部の抵抗と圧痛）が認められ, 胸部の圧 迫感があるなど，呼吸機能検査が必要と考え実施し たもので，異常所見がみられたため施術後に再度検 査を施行した15症例とした。本稿は細野史郎の学 説)を検討することを目的の一つとしていることか ら, 細野史郎の提唱する診断基準項目についても調 查した。すなわち，1）胸肋肪脹，2）肋骨弓を中 
表 2 季肋部所見と施術の効果

\begin{tabular}{|c|c|c|c|c|c|c|c|c|c|c|c|}
\hline \multirow{2}{*}{ No. } & \multirow{2}{*}{ 年齢 } & \multirow{2}{*}{ 性別 } & \multirow{2}{*}{ 主方 } & \multicolumn{4}{|c|}{ 施術前 } & \multicolumn{4}{|c|}{ 施術後 } \\
\hline & & & & $\mathrm{A}$ & $\mathrm{B}$ & C & 肺 & $\mathrm{A}$ & $B$ & C & 肺 \\
\hline 1 & 48 & 女 & 柴胡桂枝乾姜湯 & 0 & 0 & 0 & 2.33 & 消失 & 消失 & 消失 & 2.62 \\
\hline 2 & 70 & 男 & 小柴胡湯 & 0 & - & - & 3.61 & 消失 & - & - & 3.81 \\
\hline 3 & 77 & 女 & 柴胡桂枝乾姜湯 & 0 & 0 & 0 & 2.78 & 消失 & 消失 & 消失 & 3.01 \\
\hline 4 & 75 & 男 & 柴胡桂枝湯 & 0 & - & - & 3.57 & 消失 & - & - & 3.85 \\
\hline 5 & 40 & 女 & 柴胡桂枝湯 & 0 & 0 & 0 & 2.85 & 消失 & 消失 & 消失 & 2.98 \\
\hline 6 & 25 & 女 & 加味逍遙散 & 0 & - & 0 & 2.82 & 消失 & - & 消失 & 3.02 \\
\hline 7 & 67 & 女 & 柴胡桂枝湯 & 0 & - & 0 & 2.57 & 消失 & - & 消失 & 2.85 \\
\hline 8 & 24 & 女 & 柴胡桂枝湯 & 0 & - & 0 & 3.07 & 消失 & - & 消失 & 3.29 \\
\hline 9 & 46 & 女 & 四逆散 & 0 & - & 0 & 2.72 & 消失 & - & 消失 & 2.89 \\
\hline 10 & 47 & 女 & 加味逍遙散 & 0 & - & 0 & 2.61 & 消失 & - & 消失 & 2.78 \\
\hline 11 & 53 & 女 & 柴胡桂枝湯 & 0 & - & - & 2.85 & 消失 & - & - & 2.83 \\
\hline
\end{tabular}

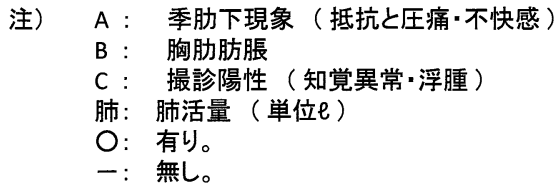

表 3 立位診により季肋下部に抵抗と圧痛を認めた群における施術効果

\begin{tabular}{|c|c|c|c|c|c|c|c|c|c|c|c|}
\hline \multirow{2}{*}{ No. } & \multirow{2}{*}{ 年齢 } & \multirow{2}{*}{ 性別 } & \multirow{2}{*}{ 主方 } & \multicolumn{4}{|c|}{ 施術前 } & \multicolumn{4}{|c|}{ 施術後 } \\
\cline { 5 - 11 } & & & $\mathrm{A}$ & $\mathrm{B}$ & $\mathrm{C}$ & 肺 & $\mathrm{A}$ & $\mathrm{B}$ & $\mathrm{C}$ & 肺 \\
\hline 12 & 61 & 女 & 加味逍遥散 & $\mathrm{O}$ & $\mathrm{O}$ & $\mathrm{O}$ & 2.28 & 消失 & 消失 & 消失 & 2.55 \\
\hline 13 & 40 & 女 & 柴胡桂枝乾姜湯 & $\bigcirc$ & $\bigcirc$ & $\bigcirc$ & 2.41 & 消失 & 消失 & 消失 & 2.54 \\
\hline 14 & 52 & 女 & 柴胡桂枝乾姜湯 & $\bigcirc$ & $\bigcirc$ & $\bigcirc$ & 2.37 & 消失 & 消失 & 消失 & 2.43 \\
\hline 15 & 49 & 女 & 柴胡桂枝湯 & $\bigcirc$ & $\bigcirc$ & $\bigcirc$ & 2.59 & 消失 & 消失 & 消失 & 2.81 \\
\hline
\end{tabular}

注) $A$ : 季肋下現象 ( 抵抗と圧痛·不快感) B: 胸肋肪脹 $C$ : 撮診陽性 (知覚異常·浮腫) 肺: 肺活量 (単位e) $O$ : 有り

心とする撮診陽性（知覚異常と浮腫）そして 3 ） 季肋下現象（季肋下部の抵抗と圧痛）である。

これら15症例について棘下筋の硬結部に症例呈示 (1)で示したと同様の施術を両側に行い, 施術前後に 上記の診断項目の診察を実施した。

\section{2。胸腹部 MRI 撮影による検討}

対象は千葉中央メディカルセンター放射線部技師 （35歳・女性）である。季肋下部の抵抗と圧痛を診 察する際に肋骨弓の下側に指頭を入れ吻側に向かっ て突き上げる力を加えることが一般的な手技である。 このような力を腹壁上から加えた場合, 横隔膜が如 何なる状態になるかを検討するために MRI 撮影を 行った。MRI 撮影装置の構造上の制約から, 自ら の右手第 $2 \sim 4$ 指で季肋下部 (右乳線上に第 3 指を 置いた）にフックをかけることにした（図２）。な お，呼吸性変動の影響を除くために圧迫の前と後は
通常の呼吸の呼気相において撮影した。被験者の腹 診においては胸脇苦満などの漢方医学的な異常所見 は認めなかった。

\section{結果}

1）15症例での検討結果。

対象15症例の詳細を表 2 と表 3 に揭げた。表 3 は 立位診 $)^{5}$ にっって右側の季肋下部の抵抗と圧痛を認 めた群である。施術後に「胸が楽になりました」

「この胸の骨の内側がスーットした」などの感想が 述べられた。表 $2 \cdot 3$ には肺活量の変化を示したが, 1 症例（症例 No11）を除き肺活量が100 300 ml 増加した。これに伴い拘束性呼吸障害あるいはその 傾向が正常方向に改善するという結果が得られた。 他方, 胸脇部皮虐の知覚異常は極めて高頻度で出現 していた。その具体的内容は多彩で, 触覚低下（症 例 No. 8), 触覚過敏 (No. $3 \cdot 5 \cdot 6 \cdot 12)$, 痛覚低 


\section{圧迫前}

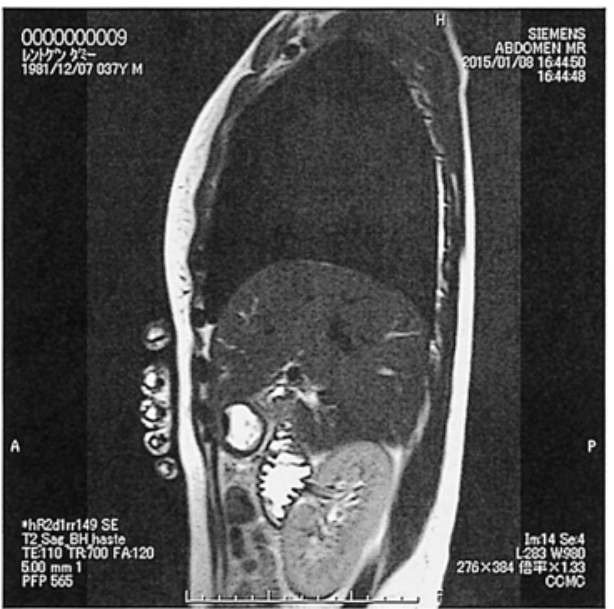

図 3 手指による圧迫前後の MRI 撮影画像（矢状断）

図 2 の方法による季肋下部の圧迫によって横隔膜が明らかに挙上伸展している。この 挙上は横隔膜の通常の呼吸性移動の範囲をはるかに超えたものである。

\section{圧迫前}

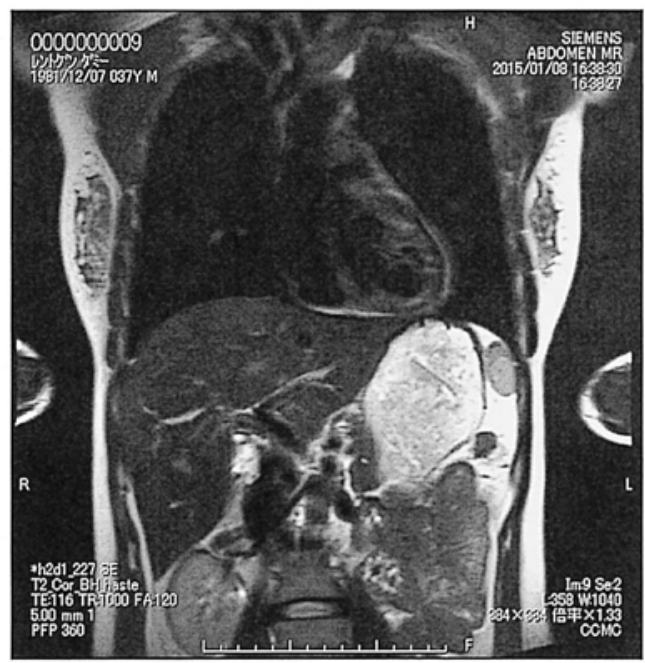

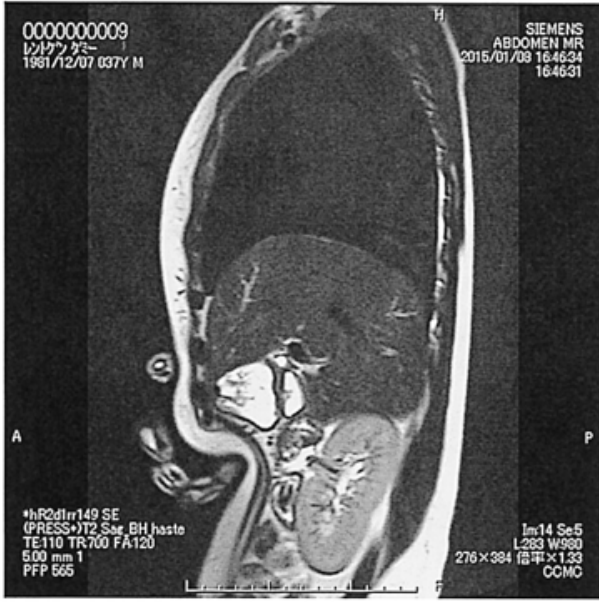

圧迫後

\section{圧迫後}

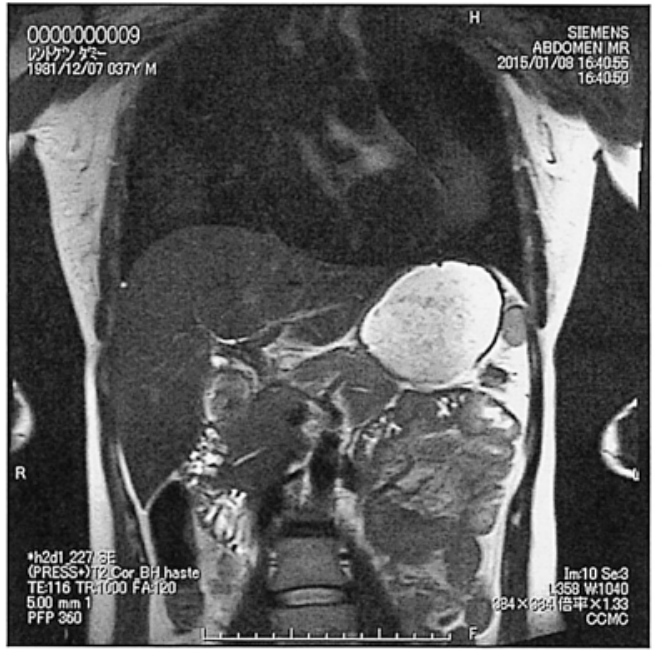

図 4 圧迫前後の MRI 撮影画像（冠状断）

右側の季肋下部の圧迫を行ったが，左側の横隔膜も挙上し，これに伴って胃の天蓋部も上方に移 動していることが示されている。右季肋下部の圧迫が横隔膜全体を伸展・挙上している。

下 $($ No. $8 \cdot 9 \cdot 14)$, 痛覚過敏 $($ No. $1 \cdot 5 \cdot 6 \cdot 7$ ・ $10 \cdot 12 \cdot 13 \cdot 15)$ であり, 症例によっては触覚・ 痛覚共に過敏なものが認められた。ただし，皮膚の 浮腫状の変化は今回の限られた対象者では認めな かった。

2 ）胸腹部 MRI 撮影による検討結果。

右乳線での矢状断 MRI 撮影画像の圧迫前後の画 像を図 3 に示した。また，同じく圧迫を加える前後 の冠状断画像を図 4 に掲げた。
矢状断画像によって明らかになったことは手指に より季肋下部にフックを掛けて圧迫することによっ て（図 2 ), 肝臓を媒体として横隔膜が伸展挙上し ていることが明らかになった。この横隔膜の挙上は 通常の呼吸性移動の範囲を遙かに超えるものであっ た。冠状断撮影画像では右側季胁下部の圧迫が左側 の胃天蓋部も挙上している画像が得られた。即ち右 側の季肋下部の圧迫は横隔膜全体を大きく挙上・伸 展させることが明らかとなった。 


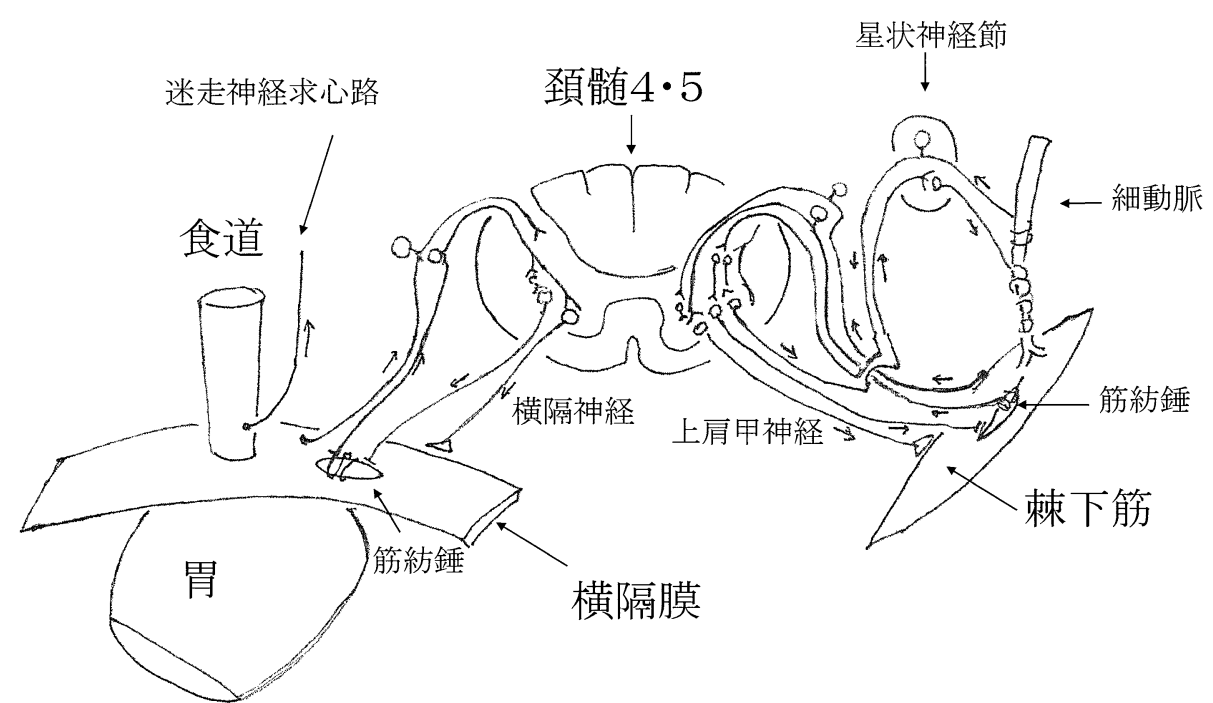

図 5 横隔神経と上肩胛神経の関連

横隔神経と上肩胛神経は双方が C 5 髄節で重なっている。左右に分けて図示した が実際には両側で同様の神経支配が為されている。施術に基づいて発生する求心 性入力には, 皮膚 · 皮下組織および筋膜に分布する知覚神経, 筋紡錘, そして細 動脈に伴走する交感神経求心路がある。この 3 系統の入力が結果的に C $4 \cdot 5$ 前角 の $\alpha \cdot \gamma$ そして交感神経細胞に negative feedback を掛けると考えられる。

\section{考察}

胸脇苦満という用語について筆者は著作的に「左 右の胁骨弓周辺の重圧感・圧迫感と, 胁骨弓下の筋 の緊張と圧痛を胸脇苦満という。すなわち, この症 候は自覚的な要素と他覚所見とによって形成されて いる」と記し, また日本東洋医学会編の『専門医の ための漢方医学テキスト』゙にも「季肋部の抵抗や鈍 痛をいう。少陽病期に現れる代表的兆候とされる」 と記されている。この胸脇苦満（季肋下部の抵抗と 圧痛）を見出す手技は胁骨弓の下に第 $2 \cdot 3 \cdot 4$ 指 を差し込むようにし，かつ突き上げる力を加えるこ とが通例である。このような手技によって胸腹腔内 はどの様な状態であるかを明らかにしたものが図 3 ， 4 である。これまで筆者は胸脇苦満を肝臓の圧痛と 単純に理解してきたが, 肝臟の圧迫と同時にこれを 媒体として横隔膜が強く挙上・伸展していることに 初めて気づかされた。

緒言にも記したように, 先の心下㾂鞕と旁脊柱筋 との関連に関する臨床的研究1)では, 旁脊柱筋への 施術は心下㾂鞭を消失ないし軽減させたが，併存し ていた季肋下部の抵抗と圧痛が軽減した症例は見ら れなかった。肝臓の圧痛を知覚する神経はその表面 の漿膜と肝門部から肝動脈に沿って走行する迷走神 経の知覚枝である。またその交感神経知覚枝は肝動
脈に伴走する。即ち, 肝臟の神経支配は胃噴門部や 胃体部とほぼ同一である。従って単純に肝臓の圧痛 が胸脇苦満という徵候を現していたならば，旁脊柱 筋への施術で心下㾂鞕と同時に胸脇苦満が消失して 良いはずである。ところが事実はこれに相違した。

そこで，旁脊柱筋以外の背部諸筋に季肋下部の所 見を消失させる硬結を広く探索したところ，棘下筋 の硬結が該当することを見出した。肩胛骨を覆う筋 肉には僧帽筋があり，その深層に棘下筋があるが， 今回見出した硬結は肩胛骨内側下端から肩関節方向 に紡錘状に存在することから，これを棘下筋の硬結

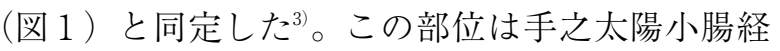
の天宗（SI11）の近傍ではあるが，全く一致するも のではなかった。

今回, 臨床的に明らかにし得た事実は以下の 4 点 である：

1 ）棘下筋（両側）の硬結に置針と加温を行うと 硬結が緩むと同時に季肋下部の腹壁緊張と按圧に対 する痛み或いは不快感（細野史郎の言う季肋下兆 候）が消失すること。

2 ) 胸脇苦満が認められる側の皮虐（Th $6 \cdot 7$ 髄節領域）に現れていた知覚異常が施術によって改 善すること(細野の言う撮診兆候の改善)。

3 ）胸脇苦満を認めた15症例の呼吸機能検査では 
拘束性の機能障害の傾向を示し，これが施術によっ て正常化する症例が多く見られたこと（細野の言う 胸肋肪脹の改善)。

$4 ） こ の$ 棘下筋の硬結は吃逆にも有効な治療ポイ ントであること。

そこで，この 4 つの事実から，従来，胸脇苦満と 称されている腹部徵候の発現機序について病態生理 学的に検討してみたい。

1。棘下筋の硬結と横隔神経についての考察。

棘下筋は C 5 - 6 に起始する上肩胛神経に支配さ れ，また交感神経線維は星状神経節に由来する。一 方, 横隔膜の知覚・運動神経は C $3 \cdot 4 \cdot 5$ に起始 する横隔神経である。即ち両神経の起始する髄節に は重なりがある。棘下筋の硬結が発現する機序とこ の部位への施術が如何なる神経回路により横隔膜に 影響を与えるかを検討したものが図 5 である。

この図では上位中枢からの信号は省略し，脊髄レ ベルのみで考えた場合の回路を示した。重要な点は $\mathrm{C} 4 \cdot 5$ レベルでの $\gamma$ 系の運動ニューロンプールの 挙動であると筆者は考えている。すなわち最初に起 こる事柄は横隔膜から発生した有害刺激信号（noxious stimuli）が $\gamma$ 運動ニューロンの興奮を起こし, 筋紡錘の収縮を来たす。これに応じて $\alpha$ 運動ニュー ロンが横隔膜と棘下筋を収縮させるのである。

胸脇苦満が出現する場合に trigger となる事象は, 横隔膜への刺激ないしは過剩伸展ストレスが考えら れる。具体的には横隔膜に吊り下げられている肝臓 の重量が馧血により増すこと, 胃の拡張と重量増加 (過食あるいは発泡飲料の摂取), 胸膜の横隔膜面 の炎症，結腸脾曲部のガス貯留そして腹膜の横隔膜 面における炎症などである。さらに大量の宿食や顕 著な内臓肥満を持つ症例では臥位において横隔膜の 吻側への圧迫・伸展が持続的に起こることから，こ れも胸脇苦満発現の trigger となると考えられる。 このような機転により横隔膜に発生した異常緊張は 呼吸運動というストレスに曝され有害刺激信号を生 じる。この信号は主として横隔神経求心路によって 頸髄に伝達される。ただし, 一部は迷走神経の求心 路，あるいは下横隔膜動脈に伴走する交感神経求心 路によって延髄或いは胸髄にもたらされる。図 5 に は横隔神経求心路による入力のみを示した。筋紡錘 からの入力が $\alpha$ 運動ニューロンを興奮させること は伸張反射として良く知られている。横隔神経以外

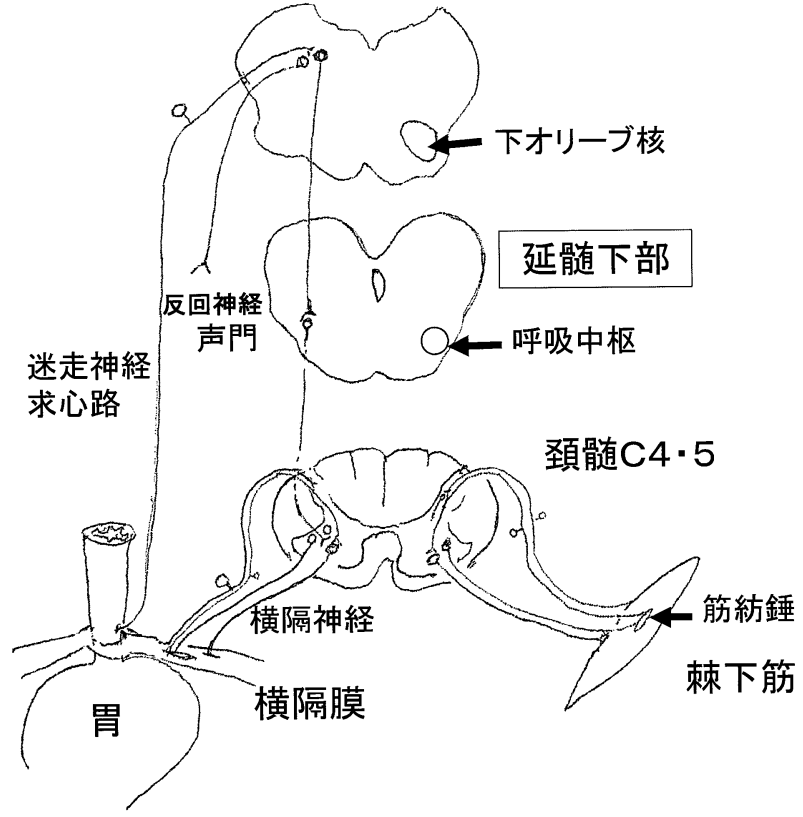

図 6 吃逆の発現に関連する神経回路と棘下筋への施術 棘下筋硬結への施術が吃逆を数分間で消失させると いう事実は, この施術が横隔神経の $\alpha \cdot \gamma$ 運動神経 ニューロンに強力な抑制をかけるものと推測される。

の求心性信号については後に逐次考察する。

図 5 に示したように, この棘下筋の硬結への施術 は上肩胛神経求心路と交感神経求心路によって C 5 を中心とした頸髄にもたらされ，この信号が $\gamma$ 運動 神経ニューロンと交感神経ニューロンに negative feedback を掛け，次いで $\alpha$ 運動ニューロンの活動性 を抑制する。この結果, 棘下筋においては血流の改 善と筋肉の過剩収縮が解除されて硬結が緩み, 同様 の機転で横隔膜においては異常な緊張状態が解除さ れるのである。結論的に言えることは，既に異常緊 張状態にあった横隔膜に, 腹診の際に術者が按圧を 加え，これを強く伸展することによって生じる痛み ·不快感の発生が胸脇苦満という徵候の主たる病態 （発現機序）であると筆者は考える。

2. 棘下筋硬結の特性を吃逆改善の切り口で考え る。

本論文において敢えて吃逆が改善した症例を掲げ たのは棘下筋の硬結と横隔膜の関連が密接であるこ とを明らかにする傍証としたいがためである。吃逆 の発現機序は未だ十分には明らかにされていないが 筆者は食道裂孔部の刺激が trigger となるものと推 測している。この部位の異常なストレッチ或いは虚 血による有害刺激信号が迷走神経知覚枝によって延 髄にもたらされ，次いで呼吸中枢に伝達され，反回 
神経（迷走神経の分枝）による声門の閉鎖と横隔神 経による横隔膜の間代性痤攣を惹起するのである。 この概念図を図示すると図 6 のようになる。肋間筋 など他の呼吸筋も当然関与するものと考えられるが, ここでは図を簡明にするために割愛した。

ここで筆者が強調したいことは, 棘下筋硬結への 施術がC 4 ・ 5 の運動神経ニューロンプールに起 こっている間代性の異常発火に強力な抑制をかける と想定される事実である。このことは棘下筋への施 術が横隔神経の $\alpha \cdot \gamma$ 運動ニューロンの活動㐫進状 態を抑制し, 横隔膜の異常緊張を解除するという筆 者の推論が相当の妥当性を持つものであることを示 唆している。

3. 内臟体壁反射の切り口での考察。

細野史郎著『漢方医学十講』には胸脇苦満という 徴候が横隔膜に関連したものであると明確に記され ており，胸脇苦満を診断する 3 項目を揭げている。

1) 胸胁肪脹 (B), 2) 肋骨弓を中心とする撮診 陽性（C），そして 3 ）季肋下現象（A）であり，A

・ B C C あるいは A C C が確認されて初めて真の胸 脇苦満と言えると記している。その根拠として内藏 体壁反射 を動員している点が特に注目される。す なわち「横隔神経を介してのものは第 6 以下第12胸 髄の, 支配下に内臟体壁反射として現れ, 知覚異常, 体液の留滞あるいは筋肉の拘攣などとして現れる。 前者は “胸肋肪脹” として, 後者は季肋下現象やわ れわれの唱える皮膚 - 皮下組織の知覚過敏や浮腫傾 向となってあらわれるものと考えられる」2)記して いる。横隔膜からの求心路を横隔神経としながら, 胸髄（Th 6 ～12）の体壁反射を起こしているとの 記述にはにわかには同意できない。内臟体壁反射は 有害刺激信号が入力した髄節近傍で起こる現象であ るからである。細野史郎の記述が為された当時には 交感神経に求心性神経が存在すること界が未だ明確 にされていなかったための龃跴であろうと筆者は考 える。なお, 細野の唱える「胸肋肪脹 $(\mathrm{B}) 」$ とい う自覚症状は横隔膜の異常緊張の結果もたらされる 呼吸機能の拘束性機能異常 (傾向) を背景として出 現するものであることがこのたびの呼吸機能の測定 結果から示唆された。

このように細野史郎が明確に胸脇苦満を横隔膜神 経症候群と結論づけた背景には, 定義が曖昧であっ た「胸脇苦満」という徵候が必ずしも柴胡剂によっ
て改善しないこと，あるいは他の方剤で改善すると いう臨床的事実から辿り着いたものである。しかし， これまで考察したように, 細野学説に言うところの 胸脇苦満の診断 3 項目の発現には頸髄と胸髄さらに は交感神経の上位中枢をも含めた反射系が存在する と考えられることから，これらの反射系と共に一つ の役割を内臟体壁反射が果たしていると考えるのが 妥当であろうと考える。その複雑な反射系の中に あって, 季肋下部の腹壁筋の緊張（按圧時に認める 抵抗）と皮虐の知覚異常の発現機序は内臟体壁反射 によるものと考えて良い。その際の胸䯣（Th6 · 7 ）への求心性信号は下横隔膜動脈に伴走する交感 神経知覚枝によると考えるのが妥当であろう。この 求心性信号に対して反射性にTh $6 \cdot 7$ 髄節の支配 領域に腹壁筋の緊張が現れ，これと共に表在知覚神 経の栄養血管（vasa nervorum）に生じる虚血が知覚 異常をもたらすと考えられる。この表在知覚の異常 は表 $2 \cdot 3$ に揭げたように出現率の高い徴候であり， 今後さらに再評価されてよい重要な記述である。本 研究に於いても, 症例 No. $12 \cdot 13$ は通常の仰臥位に よる腹診では季肋下部の抵抗と圧痛はなかったが,

右 Th $6 \cdot 7$ 領域の表在知覚の異常を認めたことか ら立位診5)を行い, 季肋下部の抵抗と圧痛を確認出 来た症例である。

いずれにせよ, 細野史郎が胸脇苦満という徵候を 横隔膜と関連づけた昫眼に敬服すると同時に今回筆 者が棘下筋硬結あるいは呼吸機能検查を根拠として 辿り着いた結論はその学説を支持し, 強化するもの であると考える。即ち, 胸脇苦満という徵候を単純 に季肋下部の抵抗と圧痛と考えてはいけないので あって, 季肋部や胸部の膨満感, 並びに Th $6 \cdot 7$ 髄節の皮膚の知覚異常などを含めたものとしてこの 用語を認識すべきであると言うことである。

4. 棘下筋硬結と天宗についての考察。

本稿では胸脇苦満という徵候と関連する筋の硬結 を背部諸筋の探索によって見出したものであり, そ の際は経穴を何ら考慮しなかった。しかし，この棘 下筋の中央部は手之太陽小腸経の天宗（SI11）であ る。天宗について代田文誌は10)「胸痛を主る。乳房 痛, 心臓部の疼痛に著効あり。五十肩, 上腕神経痛, 肋間神経痛, 肋膜炎, 上肢挙上不能等に効く。それ から右は肝障害に, 左は心障害に効く。また乳汁分 泌不足を治する妙穴である」と記している。 
図 1 に示したように棘下筋は肩峯を要として扇状 に存在するので, 解剖・生理学的視点からは天宗へ の施術と今回筆者が見出した硬結への施術は極めて 近似していると考えて良い。しかも今回の施術では 置針しこれに幅広く加温していることから，天宗を も包み込んだ施術であると理解される。ただし，こ の棘下筋硬結への施術が横隔膜の異常緊張を緩解し, 吃逆を治療するポイントとなることは筆者の独創的 新知見であると考える。

この棘下筋の硬結は肩関節周囲炎, 肩こり, 緊張 性頭痛を訴える患者などに広く見られる現象である。 一方, 胸脇苦満を呈する患者には例外なく棘下筋の 硬結が認められたことから，これを集合論的に考え ると, 棘下筋硬結という大集合の中に胸脇苦満を呈 する症例の小集合が含まれるという位置づけである。

5 。横隔膜に由来する有害刺激信号と大脳辺縁系。 ここまで専ら横隔膜の異常緊張状態について頸髄 および胸髄レベルで考察したが，この横隔膜の異常 緊張によって発生する有害刺激信号は当然の事なが ら上位の中枢神経系, とりわけ大脳辺縁系に断続的 かつ長期間に亘って不快な信号として伝達される。 この信号は情動においては易怒性や神経過敏などを 惹起し，このことが反射性に下行性の交感神経バイ アスを生じると推測される。このバイアスはさらに 横隔神経の $\gamma$ 運動ニューロンと交感神経ニューロン の活動を充進させるので，ここに一つの悪循環が形 成されるものと理解される。更に大胆に推論すれば 激しい情動が交感神経バイアスを介して胸脇苦満発 現の trigger となる可能性もある。胸脇苦満が情動 とも関連した徴候であることが今後の研究によって さらに明らかになることを期待したい。

\section{結語}

胸脇苦満という徵候が横隔膜の異常緊張と関連し て出現することを症例に基づき明らかにした。また この徵候を改善する治療点として棘下筋の硬結部へ の施術が有用なことから, その病態生理学的背景を 検討し, 細野史郎の学説を支持し, 更に強化した。 また, 胸脇苦満という用語は単純に季胁下部の抵抗
と圧痛ではなく, 季肋部の膨満感・閉塞感, 皮虑の 知覚異常などを含めた幅広い概念を示すものである ことを論じた。

付記 1) 症例呈示(1)で用いた柴胡桂枝乾姜湯加減 の構成生薬は次のと㧍りである。

柴胡桂枝乾姜湯: 柴胡5. 0, 桂枝・括呂根 - 生蚛各 3. 0 , 黄連1.0, 甘草2. 0, 乾姜1.5 (単位は $\mathrm{g}$ )。常用 処方集の黄芩を黄連と置換。

2 ）症例呈示(2)で用いた呉莱薭湯エキス製剤はツム 57. $5 \mathrm{~g}$ 分 3 ・毎食前服用である。

謝辞 季肋部圧迫に関する MRI 撮影は千葉中央メ デイカルセンター放射線部, 荒瀬佳子部長ならびに放 射線技師の皆さまの献身的な協力により提供されたも のである。記して深甚の謝意を表する。

利益相反（COI）に関して開示すべきものなし。

\section{文献}

1）寺澤捷年. 心下㾂鞕と背部俞穴との関連一心下㾂鞕の 発現機序に関する病態生理学的考察一日東医誌 $2016 ; 67: 1-12$.

2 ) 細野史郎. 漢方医学十講. 創元社, 大阪 1982. 101112.

3）森於蒬, 平澤興, 小川鼎三, 他. 解剖学 (1). 金原出 版, 東京 1961. 299.

4 ）貝沼茂三郎，伊藤隆，津田昌樹，他. 面状発熱体を使 用した電気温針器と豆電球方式の電気温針器の比較に ついて. 日東医誌 2004；55：463-467.

5 ）寺澤捷年. 新たな腹診法の工夫 立位診の提唱. 日東 医誌 $2014 ； 65: 231-235$.

6) 寺澤捷年. 症例から学ぶ和漢診療学. 改訂 3 版, 医学 書院，東京 2012. 218.

7 ）日本東洋医学会学術教育委員会. 専門医のための漢方 医学テキスト，南江堂, 東京 2010. 49.

8 ）石川太刀雄. 内臟体壁反射. 木村書店, 東京 1962. 59.

$9)$ Jyoti N.Senguputa. Visceral Pain : The Neurophysiological Mechanism. Handb Exp Parmacol 2009 ; (194) : 31-74.

10）代田文誌，銊炎治療基礎学，医道の日本社，横須賀 1969. 147. 